\title{
PATHOLOGY AND SURGERY OF BELL'S PALSY. A REPORT OF 108 CASES SUBJECTED TO THE BALLANCE-DLEL OPERATION
}

\author{
Karstex KetteI, *
}

The term Bell's palsy has been used indiscriminately for almost every kind of peripheral facial palsy, regardless of its nature. In this paper the term is restricted to cases in which facial palsy is the only clinical symptom, and in which it has not been possible to demonstrate a local cause.

The advances in understanding and treatment of this disease are especially due to Ballance and Duel ${ }^{4}$, Cawthorne ${ }^{8}$, Collier ${ }^{9}$, Hilger ${ }^{18}$ and SulJivan ${ }^{41}$.

\section{ANATOMY}

Descriptions of the anatomy of the facial nerve throughout its course can be tound in any textbook. There are also the excellent papers by Lathrop 23, Sullivan and Smith 42 and Tschiassny 45 .

In Bell's palsy the facial nerve is affected in its intratemporal course between the posterior end of the lateral semicircular canal and the stylomastoid foramen. Certain details of the pathway should be stressed.

In its peripheral part the nerve is superficially situated, but in its temporal course becomes enclosed by the rigid Fallopian canal, connected with the wall by fibrous strands running to the nerve sheath. Within the stylomastoid foramen and at its exit the nerve is compactly bound down and intimately surrounded by a cense periosteal sheath, which leaves it very little space to expand ${ }^{41}$.

A description of the blood supply is important for clinical reasons. The intratympanic part of the nerve, the mastoid cells, the semicircular canals and the tympanic cavity are mainly nourished by the stylomastoid artery, a branch of the posterior auricular, which enters the Fallopian canal at the stylomastoid foramen and runs proximally. There are two principal anastomoses. $\Lambda$ t the knee of the facial canal, posterior to the tympanum, the stylomastoid artery anastomoses with the superior petrosal branch of the middle meningeal, which enters the canal by the hiatus facialis. The second anastomosis concerns the posterior tympanic branch of the stylomastoid artery; this follows the chorda tympani in the posterior part of the tympanic cavity and on the tympanum before joining with branches to the tympanum from the internal maxillary, ascending pharyngeal, middle meningeal and carotid arteries.

Relatório apresentado ao XIX Congresso Internacional de Oto-Neuro-Oftalmologia, reunido em São Paulo em 11-17 de junho de 1954, subordinado ao $2^{\circ}$ tema oficial: Fisiopatologia do nervo facial.

* Chief-Surgeon, Frederiksborg County Hospital, Hillerod, Denmark. 
Sullivan and Smith 42 have described the arterial supply of nerves on microscopical examination. On reaching a nerve, the nutritient vessels divide into ascendIng and descending branches, which course in the epineurium. From these nrimary divisions secondary branches are given of penetrating more deeply and dividing further, being predominately arranged in longitudinal fashion in the perineural or interfascicular connective tissue and forming a longitudinal vascular bed. No one nutrient artery may be considered as dominating any portion of this plexus. But the facial nerve presents a special problem, as Hilger points out: "In the case of end-arteries without collaterals, a peripheral cataclysm may occur as, for example, in the inner ear. In a confined anatomic situation where associated edema is able by compression to prevent collateral arterial supply, an analagous condition is created. Ederna within the firm fibrous sheath of the facial nerve in the region of the stylomastoid foramen is an example."

It must be remembered that the facial nerve, in addition to supplying the facial muscles with motor impulses, also carries sensory, secretory and gustatory fibres, as described in detail by Tschiassny 45. Detailed comments on this organization will be made later.

\section{PATHOLOGY}

The primary cause of Bell's palsy is an ischaemia of the facial nerve near the stylomastoid foramen ${ }^{3,8,22,41}$ probably caused by arteriolospasm ${ }^{18}$. As a result of this, various structural alterations take place in the facial nerve between the lateral semicircular canal and the stylomastoid foramen and in some cases also in the surrounding bone. The extent of these alterations depends upon the severity of the interruption of blood supply, which may be short and transient, or prolonged. In the following the pathological anatomy, the pathogenesis and the etiology will be surveyed separately.

\section{Pathological anatomy}

Owing to the markedly benign nature of the disease it was not untill 1932, when Ballance and Duel ${ }^{4}$ proposed decompression of the facial nerve in cases of Bell's palsy, opening the Fallopian canal from the stylomastoid foramen to the lateral semicircular canal and splitting the nerve sheath, that an opportunity was offered to inspect the nerve and its surroundings in view. By this examination new ways were paved for the study of the disorder. The alterations observed in the nerve, in the mastoid cells, and in the Fallopian canal shall be described separately.

a) The facial nerve, in fresh and relapsing palsies, becomes unduly constricted at the stylomastoid foramen and edematous proximal to this point. Cawthorne describes how, in 40 out 42 cases, tiny haemorrhagic streaks were seen running longitudinally upwards within the nerve sheath. On splitting of the sheath the nerve may be seen to bulge like a hernia through the slit.

In only 4 cases so far described has the opportunity been offered to examine microscopically the facial nerves of patients suffering from Bell's 
palsy, who died from other and various causes ${ }^{1,10,29,30}$. From these it appears that the investigators found purely degenerative alterations of axiscylinders and medullary sheaths, most marked in the peripheral parts of the nerve, while inflammatory products have not been demonstrated.

Excluding all slight and dubious alterations, I have in 56 out of 108 cases found a distinct and often pronounced edema of the nerve, especially in fresh palsies of approximately $1-3$ months duration, and in relapsing palsies.

In 12 cases a violent edema of the nerve was encountered. In 9 of these the palsy had lasted 2 months or less, in one 7 and in one 9 months. This indicates that the edema may assume a subchronic character. In 3 cases the nerve was atrophic. In the first the palsy had only lasted for three months, but it started suddenly and was accompanied by severe pain, indicating complete vascular occlusion from the onset ${ }^{13}$. In the next the palsy started three years before admission, and was followed by an incomplete recovery. In the last case the patient had had 3 relapses 12 , 10 and 4 years previously, and had recovered very badly.

In a case which is the only one published of its kind I had an opportunity of making a microscopic examination of the nerve. This patient was suffering from a Melkersson's syndrome ${ }^{28}$ : facial palsy, angioneurotic edema of the lips and in some cases a lingua plicata, but everything points to the fact that the Melkersson palsy is also due to an ischaemia of the facial nerve near the stylomastoid foramen. It is referred on account of its unique position, illustrating an extreme degree of pathological alteration of the nerve and its surroundings due to ischaemia, even though not strictly a case of Bell's palsy in accordance with the definition given in this paper.

A woman aged 30 years was admitted to hospital on January 26, 1945. She had never had otitis media. Fourteen years before admission she suddenly experienced massive right-sided peripheral facial palsy, with gustatory disturbances but 'without acousticovestibular symptoms. Simultaneously she had marked oedema of the upper and lower lips, especially on the right side. This oedema remained unchanged thereafter, whereas the paresis subsided gradually though not completely, and slight contracture developed. Three months before admission the patient felt pain in and behind her left ear, but there was no discharge from the ear. Sudden massive left-sided facial palsy then occurred, with buzzing in the ear but without vestibular symptoms or herpetic eruption. The temperature was not raised. Since then the paresis has remained massive. The patient displayed the typical Melkersson's syndrome. On her right side she had partial facial palsy, slight contracture and tic-like convulsions; on her left side massive peripheral paresis. Both tympanic membranes were dull, the hearing was normal, the faradic reaction was positive on the right and negative on the left side, with a complete reaction of degeneration on the left side. Vestibular and ophthalmoscopic examinations showed normal conditions. The Wassermann test was negative. Examination of the spinal fluid revealed: $4 / 3$ cells per cu.mm (Fuchs-Rosenthal chamber), albumin less than 10 rngm, and globulin less than $1 \mathrm{mg}$ per $100 \mathrm{cu} . \mathrm{cm}$. 'The tongue and lips were affected as in Melkersson's syndrome. 'The neurological state was otherwise normal. Roentgenologically the mastoid process showed slight blurring of the cells of the left $t$ side. 
On January 29 decompression of the left facial nerve was performed, the following observations being recorded: "The superficial cells are large and glossy. In the depth around the antrum and in the cells between the posterior wall of the auditory meatus and the sinus the bone is soft, increasingly so to the part around the stylomastoid foramen. The entire facial canal is completely necrosed in its distal half, and the remaining part is opened. Neither knife nor scissors are used, but the nerve sheath is seen to be open, and from it a highly oedematous piece of the nerve bulges out, being conically pointed downward and of a grayish pink color. 'The point of the nerve, however, is of a much darker red color than the remaining part. 'The piece of the nerve projecting from the opening in the sheath is $7 \mathrm{~mm}$ long. It is resected and examined microscopically. A nerve transplant taken from the ilio-inguinal nerve is grafted" (and the mobility reappeared ten months later).

The results of the microscopic examination of the osseous tissue may be outlined as follows: 1) Superficial cells scanty, limited subperiosteal granular bony decay, bone othcrwise normal, with no signs of necrosis and no round cell infiltration; 2) Periantral cells: granular decayed osseous tissue, slight necrosis here and there, small tuffts of "cicatricially" changed connective tissue enclosing small groups of granular decayed bone, no inflammatory infiltration; 3 ) 'Tissue from the parts near the stylomastoid foramen: same as under 2.

'The microscopic examination of the nerve and the nerve sheath was recorded as follows: "Ihe nerve sheath consists of dense collagenic connective tissuc very poor in cells but enclosing small vessels and nerve branches. In the connective tissue are slight "cicatricial" alterations and a few small groups of chalky deposits. The lumen of a small venous branch contains bulging, partially connccted, slightly chalky connective tissue masses (possibly a thrombus in full organization). Otherwise the connective tissue is the seat of oedema and hemorraghe and is covered on the inside with remnants of a fibrinous exsudate. No remnants of blood pigment and no fresh-formed thrombus are seen in the vessels. On the whule the nerve is of a uniform, moderately cellular structure, still it is somewhat loose everywhere. 'The nerve filaments stain lightly, they are of unequal size and not always of a regularly circular shape in transverse sections. The nerve filaments are split by slight oedema, and the blood capillaries are engorged. Here and there small fresh punctiform hemorrhages are seen, as well as small accumulations of lymphocytes, and a few small cicatricial strands. There is no emigration of leukocytes. Special staining in the manner of Mahon showed degenerations of the medullary sheaths; moreover, there is staining of the axis-cylinders, which show distinct degenerative changes."

There is not the lightest doubt that these obvious changes (oedema of the nerve trunk, fibrinous exsudation, fresh haemorrhage and marked degeneration of axis-cylinders and medullary sheaths, a small vein containing organized remnants of a thrombus, and between nerve and nerve sheath an accumulation of fluid consisting of oedema-fluid and fibrin) are due to disturbances of the blood supply. No signs of infection, either macro or microspic, were encountered.

b) The mastoids cells. Whereas most authors have been concerned to present condition of the facial nerve, I have rather described alterations of the surrounding system: the mastoid cells and the wall of the facial canal. The aiterations of the mastoid cells fall into two groups:

Group 1 - This group comprises 6 cases: in 4 the complete palsy had lasted between 2 and 3 months, in one 5 and in the last $81 / 2$ months. 
The last 2 cases belong to the clinical group "incomplete spontaneous recovery". A very thorough medical, neurological, otological and radiological examination showed nothing abnormal apart from the facial pa!sy, especially no signs of otogenous infections. The mastoid cells between the posterior osseous wall of the external auditory canal and the sigmoid sinus, including the whole tip of the mastoid process were soft, often completely necrotic, generally dark coloured, and in one case contained a dark clear fluid. There were no signs of pus or granulation tissue. The necrotic osseous tissue was removed like butter with a curette as in a well defined mastoidits. The result of microscopic examination will be dealt with later.

Group 2 - In 14 cases the pathological alterations were only found around the stylomastoid foramen and in the tip of the mastoid process, while the rest of the cells were normal. An example may be given:

A man aged 26 was admitted on December 8, 1944. He had never had suppurative otitis media. Sixteen years before admission he suddenly experienced massive right-sided peripheral facial palsy, which subsided completely in the course of a few months. Six years later a relapse occurred, which subsided only partially. One year prior to admission massive left-sided, peripheral facial palsy suddenly appeared, not accompanied by acousticovestibular symptoms or pain. At first there was improvement, but for two months prior to admission his condition had been stationary. Facial function was decreased on both sides, most strikingly on the left side. Otoscopy, acoustic examination, roentgen study of the ears and the remaining objective examinations showed normal conditions.

Un December 11, decompression of the left facial nerve was performed, and the following record was made: "A large cellular svstem is disclosed, which is macroscopically normal. The external shell of the facial canal is enormously hard, but the interior is soft. The nerve is distinctly swollen and bulges greatly after the nerve sheath has been slit open." Microscopic examination revealed sight granular decay of the wall of the facial canal and doubtful incipient bony necrosis.

On December 27, decompression of the right facial nerve was performed, with the following observations being recorded: "The suiperficial cells are completely normal. The nerve is sought out at the stylomastoid foramen, and more than half the way to the lateral semicircular canal a focus is reached in the part deep to the facial canal. Here the bone is extremely soft and is scraped out like butter. After removal of all decayed osseous tissue, the bulb of the jugular vein has practically been reached. 'The cavity passes $1.3 \mathrm{~cm}$. below the nerve, measuring $2.5 \mathrm{~cm}$. proximodistally, and off the course of the nerve in the facial canal the funnel-shaped cavity has a width of $0.5 \mathrm{~cm}$. When the nerve sheath is slit open, the nerve bulges distinctly."

In 10 of these cases, the palsy had lasted between $11 / 2$ and 4 months. In 4 it lasted longer. Like the patients in group 1 , the facial palsy was the only clinical symptom.

Thus among 108 cases 6 were encountered in which the entire cellular system was involved, 14 in which the alterations were located to the tip of the mastoid process, around the stylomastoid foramen. 
In each case a microscopic examination was performed by Dr. Svend Petri, chief of the pathological institute of the Municipal Hospital of Copenhagen, and it agreed in showing granular decay of the bone, particularly bony necrosis, and in a single case enchondromatous alteration of the spongy osseous tissue, but never pus, round cell inflammation or granulation tissue.

c) The facial canal. Normally the wall of the facial canal is like ivory and it is a hard and time consuming task to open it, but in 26 out of 108 cases the canal was pathological. In some cases it was very pronounced:

A woman, 37 years of age. She has never suffered from otitis media. Three years before admission a complete facial palsy on the right side developed sudaenly. She recovered only partially and for the last year there had been no progress. Apart trom the palsy nothing abnormal was found.

The superficial mastoid cells were normal; around the stylomastoid foramen a necrotic cavity the size of a hazelnut was encountered, incluindg the destroyed posterior wall of the facial canal, in which a denuded atrophic facial nerve was found.

\begin{tabular}{|c|c|c|c|c|c|c|c|c|c|c|}
\hline \multirow[b]{3}{*}{$\begin{array}{l}\text { Indication for } \\
\text { decompression }\end{array}$} & \multicolumn{3}{|c|}{ Mastoid cells } & \multicolumn{2}{|c|}{ Facial canal } & \multicolumn{5}{|c|}{ Facial nerve } \\
\hline & & 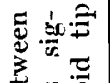 & $\cong$ & & & & \multicolumn{3}{|c|}{ Oedematous } & \\
\hline & $\underset{\bar{E}}{\bar{E}}$ & 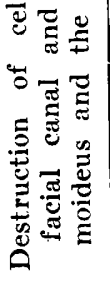 & 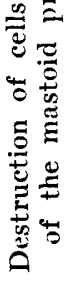 & 葛 & 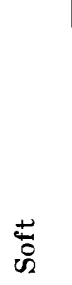 & 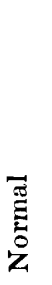 & 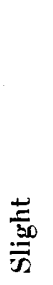 & 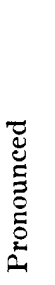 & 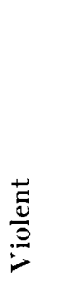 & 匏 \\
\hline $\begin{array}{l}\text { Delayed } \\
\text { recovery ... }\end{array}$ & 37 & 3 & 4 & 37 & 7 & 6 & 6 & 26 & 5 & 1 \\
\hline $\begin{array}{l}\text { Incomplete } \\
\text { spontaneous } \\
\text { recovery ... }\end{array}$ & 32 & 2 & 7 & 29 & 12 & 15 & 12 & 10 & 3 & 1 \\
\hline $\begin{array}{c}\text { Relapsing } \\
\text { palsies } \ldots . .\end{array}$ & 19 & 1 & 3 & 16 & 7 & 5 & 5 & 8 & 4 & 1 \\
\hline In ali $\ldots$ & 88 & 6 & 14 & 82 & 26 & 26 & 23 & 44 & 12 & 3 \\
\hline
\end{tabular}

Table 1 - Pathologic alterations of mastoid cells, facial canal and facial nerve in 108 cases of Bell's palsy. 1) Mastoid cells: normal in 88 cases, pathologic in 20 ceses. 2) Facial canal: normal in 82 cases, pathologic in 26 cases. 3) Facial nerve: normal or slightly oedematous in 49 cases, pronounced or violent oedematous in 56, atrophic in 3 . 
In a few cases I have seen the nerve exposed as described above, in others the canal was not open but completely soft and could be opened as far as the lateral horizontal canal in a few minutes. In some cases the exterior shell was hard, and although the interior layer was soft, this would not have been detected if there had not been a search for pathological changes. Microscopic examination showed decay of the osseous tissue proper, varying between slight and more marked.

Comments - There is general agreement over the description of the facial nerve itself in cases of ischaemic palsy, but opinions differ with regard to the pathological changes in mastoid cells and the wall of the facial canal. Hilger ${ }^{18}$ and Skinnner ${ }^{39}$ stress that my findings have not been confirmed by others with significant experience. This is partly true, but only of American and English authors, since they have been confirmed by Scandinavian surgeons. Skoog ${ }^{40}$ writes as follows in a personal communication: "From my experience regarding rheumatic facial palsy $\mathrm{I}$ am completely convinced that you are right. In my last 3 cases I remember that osseous alterations were encountered around the facial canal, immediately above the stylomastoid foramen. In one case a very pronounced hyperaemia with soft bone, in a second a discoloured and thickened mucous membrane, and in a third two small cells just near the facial canal filled with a fibrinous, yellow transudate or exsudate were found" (published by permission of Prof. Skoog).

Hall ${ }^{17}$ found in 3 cases an "exsudate in the cells at the tip of the mastoid process, and in one some larger cells containing a yellow serous fluid. The bone near the stylomastoid foramen was definitely soft, and the facial nerve highly oedematous". He later encountered a fourth case:

Case of complete Bell's palsy of 9 weeks duration. At decompression the superficial cells were normal, but in the tip of the mastoid process and in the surrounding of the stylomastoid foramen the bone was necrotic, no pus, no granulation tissue, the nerve sheath was swollen and on slitting it the nerve swelled to more than double its size.

Similar findings are reported by Flodgren ${ }^{14}$. Consequently, when comparing the descriptions of Anglo-Saxon and Scandinavian authors, it may be worth remembering the words of the American Martin ${ }^{26}$ : "Perhaps we do not get the severe neurocirculatory blocks our more northerly neighbors do".

Summarizing, it may be said in fresh and relapsing palsies the facial nerve between the posterior end of the lateral semicircular canal and the stylomastoid foramen is oedematous, and in a single case, following lack of blood supply the nerve became necrotic, with interruption of continuity. In long standing palsies the nerve is in some cases seen to be atrophied. Moreover, other Scandinavian surgeons have in some cases found exsudation in the mastoid cells and aseptic necrosis of the mastoid cells and the wall of the facial canal. 


\section{Pathogenesis}

In recent years general agreement has been reached that "Bell's palsy", "rheumatic facial palsy", or as it ought to be termed "ischaemic facial palsy", is due to vascular disturbances near the stylomastoid foramen, a dysregulation of the vasa nervorum.

Audibert, Mattei and Paganelli ${ }^{3}$ expressed the belief that when a patient gets sudden massive attack of peripheral facial palsy, after suffering, perhaps, from a half a day's or a day's pain behind the ear but otherwise displaying no abnormal symptoms, it can be explained in one way only: "The vascular supply of the nerve has been blocked". In an extremely interesting work these authors have rendered the theory of a failure of the blood supply as the cause of Bell's palsy probable, and they have maintained: "La paralysie faciale périphérique dite "a frigore" est fonction d'une atteinte artérielle des vasa-nervorum (The peripheral facial paralysis called "a frigore" is an effect of an arterial disturbance of the vasa nervorum)". They do not use the expression "une lésion", as this would imply a serious prognosis and therefore could not be applied to the slight and transient type of paresis, but they use the term "atteinte" (slight injury).

The fact that in some patients the facial nerve degenerates completely, with ensuing permanent paresis, proves that the nerve has been vitally affected. The same authors criticize the term "a frigore" and ask, "When a patient gets a hemiplegia or a hemiparesis, do we then speak of a paresis "à froid"? We don't, but we know it is a case of spasm, thrombosis or embolism, all of them dependent on a disturbance of the blood supply". Continuing, they express the view that exactly the same applies to the facial nerve: a block of the vessels of the nerve is the only way in which the suddenly occurring facial palsy can be explained; if the block does not occur suddenly, the blood supply failing only gradually, the paresis develops little by little.

This discordance of opinions may, I suppose, be only apparent, as nothing excludes the possibility that the cooling acts on the vessels of the nerve, disturbing the blood supply.

In a most interesting paper Hilger ${ }^{18}$ deals with the pathogenesis, the primary feature of which, as already mentioned, is an arteriolar constriction, the impetus being derived from autonomic nervous impulses to the vessel concerned. "It is probable that the tendency is actually inherited through the inheritance of one's autonomic system and its potential imbalances. These imbalances in the head segments are expressed in large part through vagaries in the function of the carotid arterial tree. A high percentage of patients with Bell's palsy give history of other manifestation of carotid vasomotor disturbance: chronic vasomotor rhinitis, vasodilating pain, cervical myalgia, or vasomotor labyrinthitis. 
The vessels of most vital physiologic import in any arterial trunk system are the arterioles. Because of the anatomy of their autonomic innervation in the peripheral vascular areas, arterioles tend to behave in segmental arterial branch fashion rather than in diffuse, haphazard manner. When the arterioles of a small segmental branch of the carotid tree constrict simultaneously, the resultant ischaemia produces interesting clinical conditions in the tissues supplied by that branch. The conditions may vary widely according to the cranial tissue involved. In the case of endarteries without collaterals, a peripheral cataclysm may occur as, for example, in the inner ear. In a confined anatomic situation where associated oedema is able by compression to prevent collateral arterial supply, an analogous condition is created. Oedema within the firm fibrous sheath of the facial nerve in the region of the stylomastoid foramen is an example".

Hilger ${ }^{18}$ has described the probable mechanism as follows: The es. sential features are arteriolar constriction, followed by capillary dilatation, an increase in permeability, and resultant transudation. The capillary dilatation may follow ischaemic damage, or result reflexly from the fall in venous pressure. The pressure of fluid transudates is rapidly transmitted to the walls of the lymph capillaries, and they may be closed by compression. Additional fluid then accumulates, and compression of capillaries and venules within the Fallopian canal creates further zonal ischaemia, so that a vicious circle arises.

Collier ${ }^{9}$ explains on this basis the fact that a reversible ischaemic block may be present for long periods in the nerves of the limbs without leading to permanent change, while the same block ocurring in the rigid facial canal will produce increasing vascular stasis and oedema, leading to complete degeneration. The ischaemia affects primarily the myelin sheath and has at first little if any influence on the Schwann cells and axis cylinders, which only degenerate after a prolonged lack of blood supply. In such cases the nerve may on exposure be seen to be reduced to an atrophic strand ${ }^{8,22,31,44}$.

Collier ${ }^{9}$ has called atiention to the fact that ischaemia may produce a mixed lesion, some of the axons undergoing degeneration, while others remain in a condition of reversible block and are capable of recovering. As long as the sheaths of Schwann maintain patent syncytial channels the axis cylinders can regenerate and re-establish their continuity.

From the point of view of pathological anatomy, there is no doubt that a dysregulation of the vasa nervorum takes place near the stylomastoid foramen with ensuing swelling of the nerve, which becomes secondarily compressed within the Fallopian canal. However, there has been some discussion over the exact sequence of events in pathogenesis.

The question is: is the palsy due to the primary ischaemia of the nerve, or to the secondary compression within the Fallopian canal? Bal- 
lance and Duel ${ }^{*}$ claimed that the reason for the palsy was a swelling of the facial nerve, which lost its power of conduction because it became compressed within the facial canal. But Cawthorne ${ }^{8}$, Findlay ${ }^{13}$, Hilger ${ }^{18}$ and Kettel ${ }^{22}$ have pointed out that the primary cause of the palsy is an ischaemia of the nerve, and that its power of conduction is lost following failure of the blood supply. Resulting from this lack of blood a swelling of the nerve then develops, followed by a secondary compression within the facial canal, with all its consequences. Sullivan ${ }^{41}$ also agrees that disturbance of blood supply is the first cause of this palsy, but thinks that the paralysis is a result of pressure upon the nerve following oedema in the rigid canal.

That the primary ischaemia and not the secondary compression is the reason for the nerve losing its power of conduction is illustrated by the following facts: 1) Lewis, Pickering and Rotschild ${ }^{24}$ and Denny-Brown and Brenner ${ }^{11}$ have showed that paralysis due to pressure on a nerve is entirely due to ischaemia. Grundfest ${ }^{16}$ has also shown that the pressure necessary to abolish conduction in a nerve is one which never occurs clinically. 2) Recently I have seen two patients, on whom I had earlier performed decompression, suffering from a relapse of their facial palsy as will be described later. If the palsy were due solely to secondary compression within the facial canal, a relapse would be impossible, since the nerve had previously been exposed for $3 / 4$ of its width from the lateral semicircular canal to the stylomastoid foramen.

Even if ischaemix is thus the primary cause of the paralysis, it is nevertheless a fact that a secondary compression of the nerve, and especially of its vessels, in the facial canal does occur. The power of conduction is thus further impaired, not because the nerve is compressed, but because its blood supply is further reduced.

\section{Etiology}

In this paper the term Bell's palsy is restricted to cases in which the facial palsy is the only clinical symptom, and in which it has been impossible to demonstrate a local cause. Consequently all cases in which the facial palsy is due to infections in the nighborhood are excluded. meager.

It should immediately be stated that our knowledge of the etiology is extremely

Bell's palsy is due to ischaemia of the facial nerve and the impetus to arteriolar constriction is derived from autonomic nervous impulsion 18. This however may be released in various ways, physical and emotional.

Exposure to cold has been cited as the nost common cause (as high as 70 per cent), and this is why the terms "rheumatic facial palsy" or "paresis n. facialis a frigore" are used on the European continent instead of "Bell's palsy". There is not the slightest doubt that cold may produce a Bell's palsy" and the literature contains many rather funny examples. Moreover, Sullivan and Smith 42 have experimentally proved the correctness of this fact. But on the other hand the importance of exposure to cold has been overestimated. Among Winternitz 49233 
patients, exposure to cold as an etiologic factor could only be presumed in 15 per cent.

If cold were the all important factor, more cases would be expected during the winter, and especially in very cold winters. This, however, is not the case. Winternitz 49 has pooled the statistics of various authors recording 644 cases in all: in 332 patients the palsy arose during the months April-September, in 312 between October and March.

Moreover, during the hard winters 1939-40 and 1940-4! he did not see more cases of Bell's palsy than during mild winters. Fifty per cent of my patients had been exposed to cold or draught in the days preceeding the onset; the informations, howver, were too unreliable to justify definite conclusions. Only 83 of my patients remembered exactly the time of onset (chart 1).

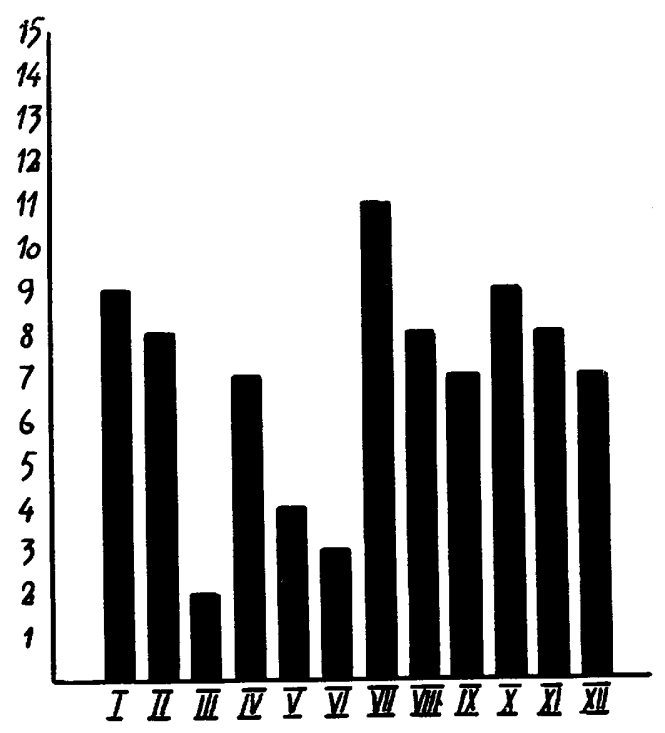

Chart 1 - 83 patients only remembered the day of onset: distribution between number of cases (115) and months (I-XII).

Finally it should be added that Bell's palsy has nothing at all to do with a rheumatic infection 49 .

Emotional strain and allergic shock may also release the mechanism leading to vasoconstriction with an ensuing facial palsy. Arrieta 2 and Bergonzi 5 have reported cases in which a Bell's palsy occurred as a consequence of sudden fright, Panneton 34 has described cases of facial palsy in connection with extraction of a tooth, and I can personally confirm both their statements.

summarizing, it may be said that our knowledge of the etiology of Bell's palsy is very meager. The nervous impulses leading to constriction of the vasa nervorum of the facial nerve, the primary cause of the illness, may be released by physical as well as emotional factors. Among the former, exposure to cold has been overestimated as an etiological factor, and terms such as "rheumatic palsy" 
or "paresis $\mathrm{n}$. facialis a frigore" should be completely abandoned and replaced by tẹrm "ischaemic palsy".

From my point of view the question of pathology narrows down to this: Bell's palsy is a pathogenetic entity, the primary and central feature being a disorder, a "dysregulation" of the circulation, in most cases affecting only the nutrition of the nerve as the most susceptible tissue. From this an ischaemic paralysis arises. In other cases the nutrition of facial canal and mastoid cells is also affected causing bony necrosis. 'The rapidity with which the paralysis begins, the degree to which it develops, the time it lasts and the degree of the pathologic changes which may be noted in the nerve and the osseous structures all depend on the size of the vessel that is blocked and on the rapidity and the degree to which the circulation is cut off and, eventually, re-established. The cause may vary, and at present not much is known about it, but the pathogenesis is in all probability the same: a primary ischaemic paresis of vascular determination.

\section{SYMPTOMATOLOGY}

'The picture of a patient with a complete peripheral facial palsy is so well known that any description would be superfluous. It should, however, be remembered that patients with Bell's palsy give history of other manifestations of carotic vasomotor disturbance, like chronic rhinitis, vasodilating pain, cervical myalgia or vasomotor labyrinthitis 18 .

In trying to check my case records for clinical symptoms $I$ have been handicapped by two facts. Firstly, my records from the early years of my work in this field are incomplete, later all the patients have been questioned systematically, using a special questionary. Secondly, most of my patients were referred to me because of delay of recovery, and many had forgotten the symptoms at the onset. Unly those patients who exactly remembered these symptoms during the first days of the palsy are included in the following report.

'The onset of the palsy may be sudden or it may develop gradually. Ninety-five were able to answer this question: in 60 it developed suddenly, in 35 gradually.

Pain, ranging from slight to rather severe, is a common symptoms in the early days of an ischaemic palsy, and that this may result from the vessels concerned is well known. It may be located in, or below, but most commonly behind the ear.

Findlay 13 has called attention to severe pain as a bad prognostic sign. In an interesting paper Findlay divides facial palsies into four groups: geniculate, neuritic, vascular and traumatic. According to the author, pains are present in geniculate and vascular but not in neuritic facial palsy; and analyzing my cases, previously reported, he expressed the view that some of them belonged to his neuritic facial group, in which the palsy is due to a neuritis "originating from tocal sepsis within its sensory field, characterized clinically by a facial paralysis without pain." I do not think Findlay's critique is justified. All my patients were subjected to a very thorough examination by all means at the disposal of a modern central hospital, and focal infection could with certainly be cxcluded in all. Moreover, apart from having excluded focal infection Findlay's own paper shows that my cases are vascular, not neuritic facial palsy, stating: "In neuritic facial paralysis all cases responded to faradism and galvanism throughout the period of paralysis till normal function returned. In vascular occlusion facial paralysis all cases lost responses to faradism, varying in time from the onset of paralysis." In all my cases of delayed recovery with a complete palsy the faradic response was negative. 
Findlay 13 is perfectly right that same patients with ischaemic facial palsy may suffer from pain and that severe pain may be a bad prognostic sign, but many cases of the ischaemic palsies are painless.

From 89 of my patients I was able to get exact information of this simptoms at the onset of palsy: 43 had suffered from pain in or especially behind the ear; in 29 of these the palsy had started suddenly, in 14 gradually. In 10 cases the pain was slight, in 29 inore pronounced, and in 4 severe. Among the 4.6 painless cases the onset was sudden in 25, and gradual in 21 patients.

Loss of taste on the anterior two thirds of the tongue was noted by 36 patients, whereas 30 did not remember having been troubled by this symptom.

A slight oedema behind the ear may be noted in the early days of a Bell's palsy, and is probably due to venous stasis. As most of my patients were referred to me because of delay of recovery. I have seen this in only 5 cases, 4 of them accompanied by pain.

Injection of the posterior wall of the cxternal neatus and the posterior part of the tympanic membrane is probably due to arteriolospasm, which can produce dilatation in their arterial trunk. Like Hilger $I$ have seen it in the first days of the palsy.

Hyperacusis results from stapedial nerve paralysis, in other patients the hearing is impaired because of a collateral oedema of the labyrinth and they often suffer from buzaing in the ear.

It is interesting to note that hyperacusis and loss of taste, which are often present early in Bell's palsy, may soon disappear in spite of continued facial palsy. 'This is probably due to relief of ischaemia through vascular anastomoses at the knee of the facial nerve, while there is no collateral supply below this level 18 (Hilger).

Seventy patients were able to answer questions about their hearing at the onset: 10 patients complained of impaired hearing and buzzing in the ear, in 60 the hearing was normal. These symptoms disappeared in a short time, in spite of persistent palsy.

Vertigo may be present during the first days. According to the theory of Mygind and Dederding ${ }^{32}$, which has gradually been universally accepted, Ménière's disease is due to an oedema of the labyrinth which is dependent on failure of the vasomotor function. 'The authors then pointed but that, just as the symptoms in Ménière's disease are caused by oedema arising in the narrow, inelastic labyrinth, so Bell's palsy is produced by oedema of the facial nerve arising in the narrow, inelastic Fallopian canal. 'This view was confirmed by the fact that in several cases they had seen an improvement of the paresis on administration of a powerful diuretic.

In 11 patients a slight vertigo was present at the start, in 61 no labyrinthine symptoms were remembered. Sixty-six patients could give exact answers as to both hearing and eventual vertigo (impairment of hearing and vertigo are probably due to a collateral oedema of the labyrinth):

\begin{tabular}{|c|c|c|c|c|}
\hline Number of patients ....... & .47 & 2 & 8 & 9 \\
\hline Hearing impaired $\ldots \ldots \ldots$ & - & + & + & 一 \\
\hline Vertigo $\ldots$ & - & + & - & + \\
\hline
\end{tabular}

Regarding the distribution between age and sex the following observations were made (table 2): 


\begin{tabular}{|c|c|c|c|c|c|c|c|}
\hline Indication for operation & Age (years) & $0-20$ & $21-40$ & $41-60$ & $>61$ & In all & \\
\hline \multirow{2}{*}{ Delay in recovery } & Male & 3 & 10 & 5 & 0 & 18 & \multirow{2}{*}{44} \\
\hline & Female & 6 & 13 & 6 & 1 & 26 & \\
\hline \multirow{2}{*}{$\begin{array}{l}\text { Incomplete spontaneous } \\
\text { recovery }\end{array}$} & Male & 2 & 4. & 4 & 1 & 11 & \multirow{2}{*}{41} \\
\hline & Female & 6 & 17 & 6 & 1 & 30 & \\
\hline \multirow{2}{*}{ Relapsing palsies } & Male & 2 & 2 & 1 & 0 & 5 & \multirow{2}{*}{23} \\
\hline & Female & 2 & 14 & 2 & 0 & 18 & \\
\hline In all & $\begin{array}{l}\text { Male } \\
\text { Female }\end{array}$ & 21 & 60 & 24 & 3 & \multicolumn{2}{|c|}{108} \\
\hline
\end{tabular}

Table 2 - Distribution between age and sex (74 women and 34 men). Facial palsy is most commonly encountered between 21 and 40 years of age. Relapses are seen almost 4 times as often in women than in men.

In my material persons between 20 and 40 years of age were most commonly afflicted, and this is in accordance with statistics by Winternitz 49, Philipp 36, Gorders 15, Bernhardt 6 and Waterman 47.

'The influence of sex is of no decisive importance. Among Müller's 33226 patients 107 were male, 119 female. Winternitz 49 treated 233 cases, 117 male, 116 female. Moreover, he added his figures to those of Philipp, Gowers and Bernhardt, and among 545 cases 51 per cent were male, 49 per cent female. Waterman 4 i reports 968 cases, 52 per cent male and 48 per cent female. Seventy four of my 108 patients were female, only 34 men, but my material is purely surgical and selected, as most of my patients were referred to me because of delay in recovery. The women were obviously more troubled by the palsy, and consequently more eager to consult a surgeon (table 2).

It may finally be mentioned that in facial palsy there is a tendency to familial history and recurrences.

'The palsy may appear suddenly or develop gradually, be complete or only partial, disapear in a short time or remain for a long period. It may be purely motor or combined with sensory or secretory symptoms, it may be restricted to the area innervated by the facial nerve itself or combined with symptoms from the neighboring organs, but everything (rapidity of development, degree, chances of recovery) depends upon one thing and one thing only: the severity of the dysregulation of the blood supply and the rapidity with which circulation is reestablished in order to avoid degeneration of the axis cylinders.

\section{DIAGNOSIS}

The term "Bell's palsy" has been used indiscriminately for almost every kind of peripheral facial palsy, regardless of its nature. In this paper the term is restricted to cases in which the facial palsy is the only 
clinical symptom, and in which it has been impossible to demonstrate a local cause.

Consequently a diagnosis of Bell's palsy cannot safely be made unless the patient has been subjected to a thorough medical, neurological, ophthalmological, otological and radiological examination to exclude a local cause, and even then one cannot be quite safe, as I have experienced twice: in one case the decompression revealed a neurinoma, in the other a sarcoma of the descending part of the facial nerve, between the lateral semicircular canal and the stylomastoid foramen, as previously described. Cawthorne has had the same experience. Provided a local causation has been excluded to the extent clinically possible, our endeavours should be directed to determing (1) the site of the lesion and (2) the condition of the nervous elements and the muscles.

Clinical topognosis - The facial nerve is, as mentioned, a mixed nerve, not only supplying the emotional muscles with motor impulses, but also containing sensory, secretory and gustatory fibres. The clinical picture is dependent upon the degree to which these different fibres of the nerve are involved and this again upon the location of the lesion. Tschiassny in two papers ${ }^{45}$ has described the signs characteristic of facial nerve lesions at 8 different levels from supranuclear to infraforaminal. Reference should be made to this paper for further information. In the ischaemic facial palsy the dysregulation of the blood supply of the nerve is located distal to the geniculate ganglion, and characteristic of this site of lesions are (1) that the secretion of tears is normal as the secretory fibres pass above this level and (2) that a partial or complete palsy of the emotional muscles with a positive Bell's phenomon is present.

If the vessels are blocked below the exit of the chorda tympani, which contains gustatory fibres to the anterior two thirds of the tongue, the sense of taste in the corresponding area is normal; if, however, the site of lesion is above this level, loss of taste results. The presence or absence of the stapedius reflex can finally tell whether the suprachordal lesion is infra or suprastapedial respectively.

The value of this topognosis of facial nerve lesion is limited and can be applied with reliability only to early lesions ${ }^{45}$. Cawthorne ${ }^{8}$ and Sullivan ${ }^{41}$ claim that loss of taste is the only realiable symptom; like Martin ${ }^{26}$ I would not even go as far as that.

Electrodiagnosis - 'l'he nerve and the facial muscles should be tested by the faradic and galvanic currents, and by electromyography:

a) Faradism is an interrupted high frequency current which gives direct stimulation of short duration to nerves; through the nerves the muscles receive the impulses to contract, normally at low intensities. If faradic response is Jost, this occurs 10-14 days after onset.

b) Galvanism is a constant current, by which the muscles are directly stimulated. The current induces a single brief contraction at the movement of clos- 
ing and breaking the circuit; normally the cathode closing current elicitates a stronger contraction than the anode closing current. The reaction of degeneration is said to be complete if faradism is absent and the anode closing current elicits a stronger contraction than the cathode closing current. It is partial if some response to faradism is present, and the polar response is modified without being reversed.

c) Electromyography: By this method it is possible to record the action current in a voluntary muscle. The aim is to obtain a quantitative estimation of the proportion of normal muscle to the denervated one which faradism and galvanism do not provide. 'The method has been described by Feinstein 12 and Weddell, Feinstein and Pattle 48 and by Collier 9 . In completely denervated muscles a rhythmic activity called fibrillation, which is a sign of an autonomous life of the muscle, occurs about the 12th day, and can be obtained as long as any contractile muscle fibres remain. If re-innervation occurs the muscles again become silent. A motor unit is the group of muscle fibres supplied by one nerve fiber. No electrical activity is detected under resting conditions in a normal muscle, but in voluntary contraction all the muscle fibres of the motor unit contract simultaneously and this can be recorded. 'Total absence of motor unit potentials and the presence of fibrillation action potentials indicate complete denervation. 'The presence of both is evidence of partial or recovering lesion. Collier 9 states that since she has had the assistance of electromyography she has not seen any case of Bell's palsy that called for decompression.

As to galvanism, there is general agreement that failure to elicite a galvanic response in muscles indicates serious atrophy and consequently contraindicates any aperation aimed at repairing the facial nerve. In such cases only plastic operations should, if necessary, be resorted to.

Opinions regarding the value of faradism as an indicator for operation differ widely. In Sullivan's 41 opinion the response to the faradic current is most important, and in questionable cases, with the patient anaesthetized he exposes the nerve directly at the stylomastoid foramen in order to be able to use a sufticiently strong current, and avoid skin resistance. Tickle 44 and Cawthorne 8 also rely upon the response to faradism as an indicator for operation. The relation of degree of paralysis and electrical conductivity to spontaneous recovery in 151 cases of Bell's palsy treated by Cawthorne 8 is illustrative:

\begin{tabular}{l|c|c|c}
\hline \multicolumn{1}{c|}{ Faradic response } & Full recovery & $\begin{array}{c}\text { Partial } \\
\text { recovery }\end{array}$ & $\begin{array}{c}\text { No recovery } \\
\text { within two } \\
\text { months }\end{array}$ \\
\hline $\begin{array}{l}\text { Incomplete paralysis } \\
\text { Faradic response normal } \ldots . . .\end{array}$ & 0 & 4 & 41 \\
$\begin{array}{l}\text { Complete paralysis } \\
\text { Faradic response normal } \ldots . . .\end{array}$ & 0 & 4 & 20 \\
$\begin{array}{l}\text { Complete paralysis } \\
\text { Faradio response reduced } \ldots . . .\end{array}$ & 0 & 8 & 14 \\
$\begin{array}{l}\text { Complete paralysis } \\
\text { Faradic response absent } \ldots . . . .\end{array}$ & 57 & 3 & 0 \\
\hline
\end{tabular}

'This statistics makes Cawthorne's 8 standpoint perfectly clear. However, it is interesting to note that even a normal faradic response in a complete as well as an incomplete paralysis is not warrant of full recovery, a fact to which I have earlier called attention. 
Like Martin 26, Violé ${ }^{46}$, Findlay 13 and Mayer 27, I consider the faradic response an unrealiable indicator, having seen many a patient with negative faradic response recover completely under conservative treatment. Previously I tried to explain this fact: when a muscle is paralyzed, its electric excitability immediately increases; i. e. the chronaxie of the muscle is shortened, which means that a stimulus of shorter duration is capable of exciting contractions. After a short period of time, however, the excitability of the muscle decreases; in other words its chronaxic is extended, so that a stimulus of longer duration is required to excite contractions. The faradic current is a high frequency alternating current and the fact that the faradic reaction becomes negative just means that the stimulus is inadequate hecause it is of too short duration to excite contractions of the musculature, the chronaxie of which has become extended. Therefore, no safe conclusions as to the prognosis of the paresis can be drawn from a negative faradic reaction.

However, I must admit that I never exposed the nerve and applied the current while the patient was anaesthetized, as suggested by Sullivan 41.

From the papers cited above, it is an established fact that patients with a negative faradic response may recover spontaneously and completely and that not even a normal faradic response is a guarantec for full spontaneous recovery.

Regarding electromyography opinions also differ: Sullivan ${ }^{41}$, House ${ }^{19}$ and Violé 46 have found it of little value, Martin 26 , Bunnell 7 and especially Collier 9 very important. Bunnell $z$ states that its results are 90 per cent reliable, but as an emergency guide it is useless, as it is not of value before 21 days from the onset. Electromyography may tell whether a muscle is completely denervated or not, but by this method it is impossible to distinguish between a complete division of the nerve, where spontaneous regeneration is excluded, and interruption of axons with preservation of the supporting structures, in which axons can regenerate along the old paths. Only exploration can distinguish between the two lesions.

Especially regarding Bell's palsies "we are dealing with cases where the original injury has produced an interference with conduction which of itself is temporary and recoverable, but where persistence of the compression in the rigid tacial canal can produce changes which may lead to degeneration" (Callier ${ }^{9}$ ).

Personnally I have no experience with electromyography.

Summarizing, it may be said that a negative galvanic response indicates a serious atrophy of the muscles and contraindicates any operation on the facial nerve; but that opinions differ widely as to the value of the faradic response and electromyography. The latter reaction may be an adjunct, but should not be relied on exclusively more than any other factor ${ }^{26}$. When more experience is gained with electromyography, perhaps problems may be solved, which cannot be overcome today.

\section{THERAPY AND PROGNOSIS}

Knowing practically nothing about its etiology we cannot prevent Bell's palsy from arising, but can only try to combat the primary cause, the ischaemia, and prevent or at least reduce the secondary compression within the facial canal.

Medical treatment is the therapy of choice as it aims at correcting the primary disturbance of the vasa nervorum, and has resulted in the complete recovery of $75-85$ per cent of cases. On the present indications 
surgery can only aim at correcting the sequels, oedema, compression, and possibly an angulation of the nerve at the point of vasoconstriction. Decompression is definitely indicated in a limited number of cases, but to find a sound basis for surgical intervention is the great problem of today.

The therapeutic results obtained by both types of treatment will first be analysed separately, and an attempt will then be made to outline the indications for operation.

Medical treatment - Previously only heat, massage and electrotherapy have been used in order to keep the muscles alive until re-innervation has taken place. Since it has been established that ischaemia is the cause of the palsy a physiological approach has been proposed, with the aim of correcting the existing vasospasm and reabsorbing transudates. For this purpose drugs with vasodilator effect have been used, such as nicotinic acid, intravenous histamine, and paverine 18, 20, 25, 39. Sympatholytic drugs have also been tried, such as ergotamine tartrate and tetraethylammonium chloride, as well as cervical sympathetic block. Lately cortisone has been proposed, and good results reported 38,43 .

Following these lines, complete recovery has, as stated, resulted in 75-85 per cent of cases. A paper by Parker and Watkins 35 is incomplete as they only followed 302 of 440 cases through the significant part of the disease. Muiller 26 has published a follow-u! of 203 patients treated conservatively (by electrotherapy alone). In 79 per cent a complete recovery was obtained, in a further 18 per cent insignificant paralysis remained, while in 3 per cent the palsy remained severe. Unfortunately Müller's material is selected, as he excluded all patients who on first admission had reached the age of 40 years, as well as patients who had had paralysis of more than 14 days' standing. Moreover, most of his information is derived from questionnaires, and not from a personal re-examination of his patients. A comparison is not therefore possible between his paper and the present report:

Much better for this purpose is a report by James and Russell 21. Many of their patients, like mine, were referred because of delay in recovery. They examined a group of 58 patients. In 30 cases a complete cure followed spontaneously. In 29 of these the firsi movements began within two months, and in the remaining one between the third and fourth months. But even a comparatively early return of movements does not guarantee complete recovery. In 11 of their patients the spontaneous movements began between one and two months after the inset of palsy, and nevertheless none of them recovered completely. Neither were any of the 17 patients completely cured in whom movements started after two months of observation. There can hardly be any doubt that the patients who recover completely are those who have had a transient block of the vasa nervorum, and in whom no degeneration of the axons has taken place. In all the other cases the nerves have to recover by regeneration, which gives unsatisfactory results

Surgical intervention - Although medical treatment is the method of choice, surgery is nonetheless definitely indicated in a limited number of cases. But the therapeutic problem is one of great difficulty. We do not know in any given case to what extent the palsy is due to primary ischaemia, or to what extent it follows secondary compression within the rigid canal. The primary condition cannot be influenced bu any operation available, while the secondary may be helped by decompression. 
In selecting cases for operation many authors ${ }^{8,41,44}$ rely completely, as already mentioned, upon the response to the faradic current, claiming that a complete recovery will never take place when the response is negative. Others ${ }^{22,26,27,37,46}$ however, do not consider this a reliable indicator, having seen many patients with a negative response recover completely. In exactly the same way opinions differ regarding the value of electromyography ${ }^{9,4 x}$.

Personnally I have operated on 108 cases of ischaemia palsy. These comprised 74 women and 34 men, and 60 of them were between 21 and 40 years of age. With very few exceptions $I$ have been able to re-examine personnally all the cases; the remaining few were examined by their own doctor.

Decompression was performed on the following indications:

a) Delay in recovery - The majority of the cases showed no signs of recovery after two months of observation. The time limit is based upon the fact that upon re-examination of 169 cases of otitic palsy, which were conservatively treated as regards the nerve, a complete recovery was never seen when the first signs of spontaneous movement began later than the second month. In Cawthorne's experience ${ }^{8}$ the movements start within 3 weeks if spontaneous recovery is going to be complete. As already mentioned the report of James and Russell ${ }^{21}$ shows that in ischaemic palsies, too, a complete recovery was never seen when mimicry began later than the second month.

The group operated on this indication comprises 26 women and 18 men. They all had a complete palsy, with negative faradic response, and in the majority of cases decompression was performed ca. 2 months after onset. In 39 of the 44 cases treatment is finished, and all these have been re-examined.

The results are as follows: 1) Duration of the palsy: Less than 1 month, 3 cases; 1 month, 5 cases; 2 months, 23 cases; 3 months, 6 cases; 4 months, 1 case; 5 months, 1 case. 2) Appearance when the face was at rest: 35 patients looked perfectly normal; in 3 patients the palpebrae fissure was a little diminished on the side affected; in one patient there wa sa very slight contracture. 3) Degree of movement: 33 patients could move the forehead to varying degrees; 39 patients could close and screw their eyes up; 6 patients had recovered completely (fig. 1D); the palsy had lasted in four cases for 2 months, and in one for $2 \frac{1}{2}$ and in the last for 3 months; 21 patients could smile to the degree shown in fig. $1 \mathrm{C}$; 12 patients could smile to the degree shown in fig. $1 \mathrm{~B}$. In all cases synkineses ranging from extremely slight to rather pronounced were noted.

It is impossible to tell what the result would have been without decompression. The criticism has often been raised that the surgeon has taken credit unjustifiably for improvements following decompression, and 
there is no doubt that many of these patients would have recovered at least partially without the operation.

"Rapid return of function sometimes claimed for decompression, occurring in a matter of days, cannot be due to regeneration of the nerve fibers" (Collier $\left.{ }^{9}\right)$. This is of course perfectly correct, but the explanation of this rapid return of function, which Cawthorne ${ }^{8}$. Sullivan ${ }^{41}$ and I have seen in many cases, is that decompression has removed the pressure on nondegenerated axons and their vessels within the facial canal.

Other facts have convinced me that in cases of delayed recovery decompression has hastened and improved the final result. Among the patients of James and Russell ${ }^{21}, 17$ had had a palsy of more than two inonth's duration, and none of these recovered completely: "In 10 cases there was obvious contracture of the previously paralyzed side, and in 3 cases this was severe". Thirty of my patients in this group, in which the treatiment is finished, came to operation ca. two months after the onset, and of them 6 recovered completely (fig. $1 \mathrm{D}$ ), 15 to the degree illustrated in fig. $1 \mathrm{C}$ and 9 as in fig. 1 B. In only a single case was a slight contracture noted.

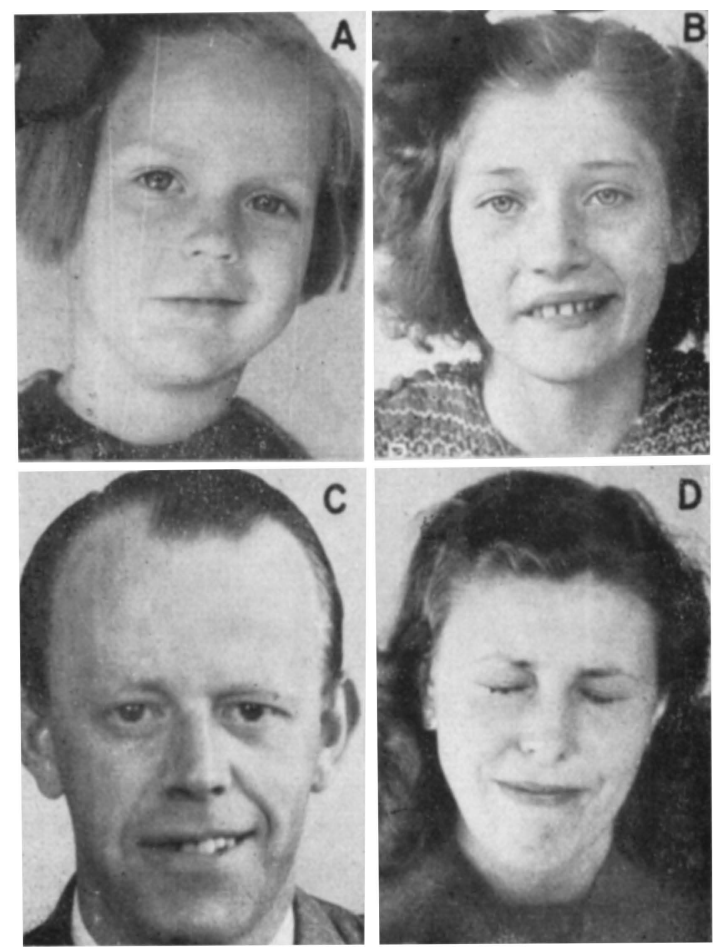

Fig. 1 - Different degrees of mobility ubtained by decompression. 
It appears therefore that decompression counteracts the development of contracture, and moreover, can make a manifest contracture disappear, which I have seen 3 times.

Consequently, comparison between the results obtained in palsies showing delayed recovery by medical ${ }^{21}$ and by surgical ${ }^{22}$ treatment, shows that surgery definitely gives better results, but also that complete recovery is the exception, certainly not the rule. Contractures are almost completely avoided, and the synkineses seem to be less pronounced than in cases treated medically, a point to which Cawthorne ${ }^{8}$ has called attention.

Could still better results have been obtained by prompt decompression, which is to be understood an emergency operation? Bunnell ${ }^{7}$ recently stated as follows: "The only possible time for prophylaxis or prevention of Bell's palsy is during the first few hours - three, if the blockage of circulation is complete, but a few more if partial. Prompt decompression will keep the nerve alive. If decompression is not done, then the ischaemia will result in a degree of damage to the nerve ranging from temporary palsy to permanent paralysis".

The word "prompt" should be stressed. I have operated on 3 patients 7,8 and 12 days after the onset respectively. In all of them great oedema of the nerve was found, but in spite of the fact that the pressure was thus comparatively soon relieved, the operations proceeding smoothly, the end results were among my poorest.

Any operation as a routine method at the onset of palsy is of course out of the question, since 75-85 per cent of all ischaemic facial palsies recover under medical treatment, and we have at present no means of recognising the 15-25 per cent of more serious cases, either by clinical examination or by tests. Regarding the fresh palsies Martin ${ }^{26}$ says that "since no criteria for immediate operation are agreed upon, more nerves will be saved by medical therapy than by perhaps unnecessary surgery". I quite agree with Martin, and moreover I should like to add that even if we did know in which cases medical treatment would fail, some operation which could deal with the underlying cause of the primary vasoconstriction, would be the method of choice, rather than decompression. As long as an ideal procedure is not available for this purpose, we would have to content ourselves with decompression in these 15-25 per cent of more serious cases, while fully realizing that by decompression we dea! only with the secondary compression within the facial canal of the facial nerve and its vessels, and not which the real cause of the palsy.

Consequently, when confronted by a patient with fresh palsy, we do not today know when to operate and the ideal operation is not available. We only know that in cases where no signs of returning mobility have appeared after two months of observation, a complete recovery is highly improbable, and that decompression in these cases had proved its value. Lntil better tests are available, I shall continue to observe my patients 
for two months before contemplating a decompression. But Cawthorne ${ }^{8}$ may be perfectly right in stating that if after one month of observation the faradic response is negative, and no signs of spontaneous movement have appeared, decompression should be seriously considered.

Lastly it should not be forgotten that the diagnosis may be wrong. In 2 cases I have found a tumor (one neurinoma, one sarcoma) on the descending part of the facial nerve within the Fallopian canal, and Cawthorne ${ }^{8}$ has had the same experience.

b) Cessation of the spontaneous recovery of nobility before complete restitution is obtained - This is my second indication for operation. Whereas it is impossible to tell with certainty how much a patient with a complete palsy has gained by decompression, it is easy to evaluate the effect of the operation in cases where the spontaneous return of movement has stopped short of complete recovery. A resumption of improvement after a pause has never been observed when spontaneous recovery has once ceased at a certain stage.

The effect of decompression on cases in this group is illustrated by the following example:

A man 17 years of age had developed an ischaemic palsy of the left side, becoming complete in 6 hours, 7 months before admission. He gradually improved under conservative treatment, but the improvement stopped after 5 months (fig. 2 A). Apart from the palsy nothing abnormal was found by a very thorough examination. 'Iwo months after the improvement had stopped, or 7 months after the onset, a decompression was done. The mastoid cells were extremely haemorrhagic, and the bone around the mastoid foramen soft. The facial canal was normal, but the nerve oedematous. The immediate improvement is clearly seen on comparison of figures $2 \mathrm{~A}, \mathrm{~B}, \mathrm{C}$. The first photograph (fig. 2 A) was taken before, and the two others (fig. $2 \mathrm{~B}, \mathrm{C}$ ) six hours after the operation.
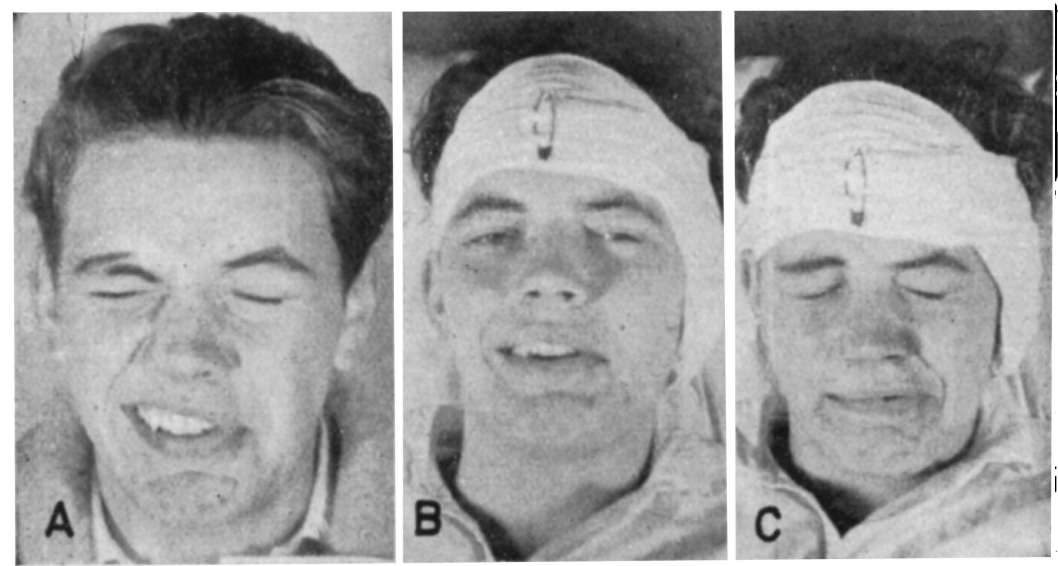

Fig. 2 - A: maximal degree of mobility before the operation. B and C: six hours after decompression on the left side. 
The same prompt results have been obtained in several other cases. Morris ${ }^{31}$ performed a successful decompression on one of his patients 8 years after the onset, and I can add several cases where the patients had recovered only partially and where decompression performed years later improved the condition.

Two of the most unbelievable cases shall be recorded. Both of the patients consulted me because they had seen other patients with a similar story who had improved considerably after decompression. They were told that nothing could be promised, but they insisted upon operation and decompression was done, as I had at that time never seen a case get worse after operation.

1) Woman, 20 years of age; 16 years before admission a complete ischaemic palsy developed on her left side, she improved gradually but very incompletely. She was unable to wrinkle her forehead, the left palpebrae fissure was bigger than right and she was unable to close the eye completely, a $4 \mathrm{~mm}$. gap remaining. 'The left corner of the mouth drooped a little, and she could hardly move the left side of the face; drums and hearing were normal and apart from the palsy nothing abnormal was found. The superficial mastoid cells were normal, but near the stylomastoid foramen, including the whole tip of the mastoid process, the bone was necrotic and the wall of the facial canal soft. The nerve looked normal on slitting the sheath.

I have not seen the patient since, but 8 months after the operation I got the following letter from her aunt: "She is able to close her eye, "smile" with her eye and is able to move the left corner of her mouth a little when smiling and laughing, all of which movements she was unable to perform before the operation. I am extremely satisfied by the result and she thinks herself that she looks much nicer than before the operation. Best of all she has got rid of her complexes and is much freer when together with her friends". Probably the progress has only been small, but nevertheless of great value to the patient.

2) Woman, 42 years of age; 14 years before admission a complete and typical ischaemic facial palsy developed on her left side. She improved gradually but during the last 6-7 years no progress was seen. The palsy could not be noted when the face was at rest; she could close her eye, but the ability to move the corner of her mouth was rather poor and she was suffering from a very troublesome feeling of stiffness in her cheek. Drums, hearing and everything else were normal. 'The mastoid cells, the facial canal and the nerve looked normal. Two days after the operation she said that she had got rid of the feeling of stiffness in her cheek, that she could move the mouth more freely, and that fluid did-not, as before, come out of the left corner of the mouth when drinking. Four months later she had improved further, especially she was able to move her mouth and cheek more freely than before operation and she was now able to show her teeth completely, which had been impossible before. Again: minor progress (and this patient I have seen myself), but of great value to the patient.

My patients falling into this group number 30 women and 11 men; 25 patients have been operated on less than 1 year after onset, 5 more than 1 year and 11 more than 2 years after the spontaneous return of movement had stopped. Two died years later from causes which had nothing to do with their facial palsy. 
The remaining 39 have all been re-examined: Considerable improvement followed in 19 cases; two of these, who were decompressed 3 weeks and 2 months after the cessation of spontaneous improvement, recovered completely (fig. 2 D). In 11 cases a moderate improvement resulted, which was, however, valued by all the patients; in 3 cases the improvement was only slight; in 2 cases the result is doubtful; in 3 cases there was no improvement, but one of these was relieved of a troublesome headache and a feeling of stiffness in the cheek; in one case the patient was worse than before operation.

From this it can clearly be seen that decompression may give valuable results even when the operation is done years after spontaneous improvement has stopped. Further, many patients are either completely freed of annoying stiffness of the cheek, or have this symptom significantly !essened. Finally a contracture diseappeared in 3 cases after decompression (fig. 3).

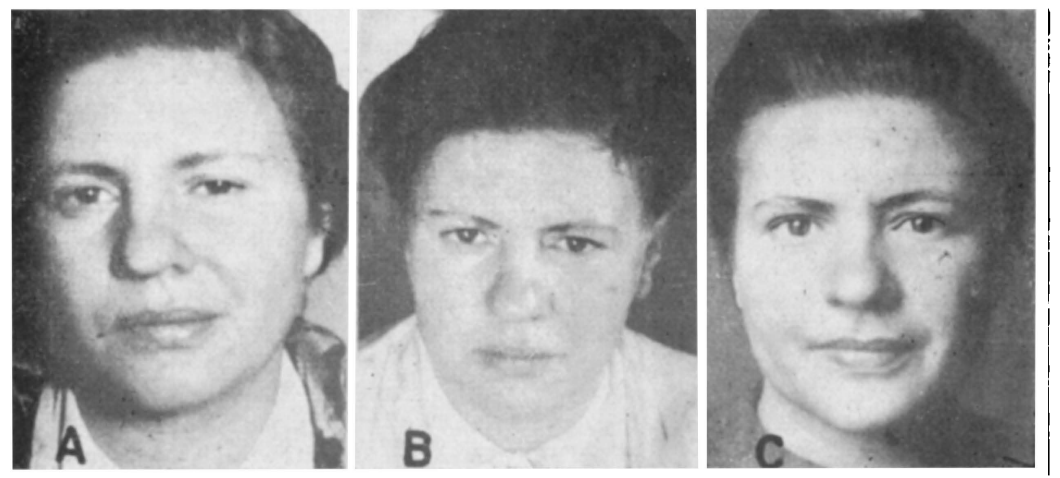

Fig. 3 - A: Bell's palsy of seven month' duration on the left side, with contracture. B: appearance of the patient the day after the operation; the contracture disappeared immediately after decompression without the slightest impairment of the mobility. C: $2 \frac{1 / 2}{2}$ years after decompression.

I must, however, give a strong warning against performing the operation on insufficient indications, as it is impossible to tell beforehand whether improvement will result. The outcome depends upon the extent to which the remaining palsy is due to permanent degeneration of the nerve, on which decompression can have no effect, or is due to pressure in the facial canal, which may be relieved by operation. The one case should also be remembered in which a patient got worse in spite of an operation which appeared perfect to the naked eye.

If the power of movement is very bad, if the galvanic response is strongly positive, and if on decompression an atrophic nerve is found, the best course is to resect this part of the nerve and put in a graft. 
c) Relapsing palsies: There has hitherto been unanimous agreement between Cawthorne ${ }^{8}$, Sullivan ${ }^{41}$ and myself that decompression prevents a recurrence of the palsy. In 14 years I have operated on 23 patients with relapsing palsies, but only recently have I seen two patients, by chance both at the same time, who suffered from a recurrence on the side previously decompressed. These relapses occurred 11 years and 1 year after their respective operations. In both, however, the palsy disappeared again spontaneously and completely in a short time.

This is clinically a very distressing phenomenon, but most interesting from a pathological point of view. It confirms as already mentioned that the primary cause of palsy is ischaemia of the nerve not the secondary compression, and also suggests that not in all cases does the decompression lead to the setting up of a collateral blood supply. I had previously assumed that this always occurred.

The group comprises 23 patients, 18 women and 5 men, who had had attacks of palsy from 2 to 9 times. The operation was done shortly after the recurrence. The results were: a) 4 patients recovered fully after decompression; in one case a relapse occurred 1 year later with ensuing complete spontaneous recovery; b) 14 patients recovered with only minor defects; c) having spontaneously recovered only partially after their first attack, 5 patients regained movement to the same extent after decompression; in one case a relapse occurred 11 years later with ensuing recovery to the same extent as before.

I have always previously maintained that decompression was absolutely indicated as soon as a recurrence took place, and that it would prevent a further relapse. But observation of the two recurrences in spite of previous decompression has made me alter this indication, and I now treat jatients with a relapse in the same way as cases of fresh palsy. They are observed for two months under careful conservative treatment, and a decompression is performed at the end of this time if no sign of returning movement can be noted.

In contrast to the skeletal muscles, which are compact structures, bound together by a clearly defined fascia and acting as a unit, the facial muscles are extremely thin and delicate, lying directly under the skin, attached to the latter and to the eyelids and the lips. They are not covered by any fascia which enables small parts to contract independently of the rest of the muscles. Streching of the skin, into which the muscles are inserted, muscle atrophy resulting from disuse, and overstretching by the pull of the muscles on the sound side are factors which counteract recovery, and consequently it is all-important that the muscles should be supported and exercised by all means at our disposal until reinnervation has taken place. Even then the result may be imperfect, because the number of regenerating nerve fibres reaching the muscles are insufficient and poor quality so that many muscle fibres are never reinnervated (Collier ${ }^{9}$ ). This author 
calls attention to the fact that $\mathrm{m}$. frontalis, $\mathrm{m}$. levator labii superiores alaeque nasi and the muscles which are inserted into the upper and lower lip often fail to regenerate.

The re-examination of my patients confirm Collier's statement completely; 101 patients have been re-examined and only 12 recovered completely, but by this it should be understood that ail the muscles, even the smaller groups, regained full mobility; 15 per cent were unable to wrinkle the forehead; 25 per cent were unable to wrinkle the nose; 36 per cent were unable to raise the upper lip; 47 per cent were unable to lower the lower lip.

But the principal aim of our therapy is (a) to make it possible for the patient to close and screw the eye up and (b) to regain a normal appearance when the face is at rest and be able to smile and, at least partially, to laugh, and fortunately those are the movements which most easily are restored, whether a decompression, a nerve graft or a nerve suture have been performed.

I have tried to show that surgery performed on present indications has given results which could not have been obtained with a conservative treatment, and like Cawthorne ${ }^{8}$, "I have no doubt that in severe cases decompression ensures the maximum amount of recovery". But the results are not good enough. Not until reliable tests are available, which can immediately distinguish the cases which will recover spontaneously and completely from those which will not, and not until an operation which deals with the primary cause of the palsy, the ischaemia, will better results be obtained. Decompression, relieving only secondary compression within the Fallopian canal, is not adequate.

\section{SUMMARY}

The majority of cases of Bell's palsy are due to ischaemia of the facial nerve near the stylomastoid foramen. Following lack of blood supply the nerve loses its power of conduction, and venous stasis arises with ensuing swelling of the nerve, which becomes secondarily compressed within the Fallopian canal.

The therapy of choice is medical treatment aiming to relieve the vasoconstriction and maintain the contractility of the muscles. Surgical decompression of the facial nerve is indicated in a limited number of cases, and the results of 108 operations are briefly recorded.

Decompression should be performed in both fresh and relapsing palsies if no signs of spontaneous movement are observed after two months of observation. With patients in whom spontaneous recovery has ceased befored complete restitution has been obtained, further improvement may be expected from decompression. 


\section{BIBLIOGRAPHY}

1. Alexander, G. - Zur klinik und pathologischen Anatomie der sogennanten rheumatischen Facialislïhmung. Arch. f. Psychiat., 35:778, 1901-1902. 2. Arrieta, A. - Sur un cas de paralysie faciale d'origine emotive. Rev. de Laryng., 46:599, 1925. 3. Audibert, V.; Mattei, C.; Paganelli, A. - La paralysie faciale périphérique dite "a frigore" est fonction d'une atteinte artérielle des vasa nervorum. Presse Méd., 44:1049, 1936. 4. Ballance, C.; Duel, A. B. -- 'The operative treatment of facial palsy. Arch. Otolaryng., 15:1-70 (January) 1932. 5. Bergonzi, M. - Paralisi del faciale "ex emotione". Zentralbl. f. Hals-, Nasen- u. Ohrenh., 35: 479, 1943. 6. Bernhardt - Cit. by Winternitz 49. 7. Bunnell, S. - a) Suture of the facial nerve within the temporal bone. Surg., Gynec. a. Obst,, pg. 7-12 (July) 1927; b) Surgical repair of the facial nerve. Arch. Otolaryng., 25:235-259, 1937; c) Summation of papers on management of facial paralysis. Arch. Otolaryng., 55: 417 (April) 1952. 8. Cawthorne, T. - a) Peripheral facial paralysis. Some aspects of its pathology. Laryngoscope, 56:653-664 (November) 1946; b) The pathology and surgical treatment of Bell's palsy. Paper read at the Fourth Interriational Congress of Neurology, Paris, 1949; c) Bell's palsy. Lancet, no. 6683, pg. 593 (September 29) $1951 ; d$ ) The rôle of surgery in the investigation and treatment of peripheral facial palsy. Lancet, pg. 1219 (June 21) 1952. 9. Collier, D. J. - a) Discussion on the limitations of operative treatment in traumatic tacial paralysis. Proc. Roy. Soc. Med., 34 (March 7) 1941; b) The present position of facial nerve surgery. Ann. Otol., Rhin. a. Laryng., 58:686 (September) $1949 ; c)$ The treatment of facial paralysis. Proc. Roy. Soc. Med., 43:746, 1950. 10. Dejerine, J.; Théohari, A. - Un cas de paralysis faciale périphérique dite rheumatismale, ou a frigore, suivi d'autopsie. Compt. Rend. Soc. Biol., 4:1033, 1897. 11. Denny-Brown, D.; Brenner, C. - a) Lesion in peripheral nerve resulting from compression by spring clip. Arch. Neurol. a. Psychiat., 52:1 (July) 1944; b) Paralysis of nerve induced by direct pressure and by tourniquet. Arch. Neurol. a. Psychiat., 51:1 (January) 1944. 12. Feinstein, B. - The application of electromyography to affections of the facial and the intrinsic laryngeal muscles. Proc. Roy. Soc. Med., 39:817 (October) 1946. 13. Findlay, J. - Facial Paralysis. Angus and Robertson Ltd., 89 Castlereagh St., Sydney, 1950. 14. Flodgren, F. Contributions to the surgery of facial palsy. Aeta Oto-Laryng., suppl. 74, pg. 188, 1948. 15. Gorders - Cit. by Winternitz $\$ 0$. 16. Grundfest - Cit. by Lewis et al.24. 17. Hall, A. - a) Pathology of Bell's palsy. Arch. Otolaryng., 54:475 (November) 1951; b) Private communication to the author. 18. Hilger, J. A. The nature of Bell's palsy. Laryngoscope, 59:228-235 (March) 1949. 19. House - Cit. by Lathrop 23. 20. Ingelstedt, S.; Thees, J. - Intravenös histamindropp vid Bell's paralys. Nord. Med., 48:1732, 1952. 21. James, J. A.; Russell, W. R. - Bell's palsy. Lancet, no. 6682, pg. 519 (September 22) 1951. 22. Kettel, K. a) Bell's palsy; pathology and surgery; a report concerning fifty patients operated on after the method of Ballance and Duel. Arch. Otolaryng., 46:427 (October) 1947; b) Um den sakaldte rheumatiske facialisparese set fra et kirurgisk synspunkt. Ugesk. f. Laeger, no. 10, p. 353 (March 5) 1953; c) Neurinoma of the facial nerve. Arch. Otolaryng., 44:253, 1946; d) Intratemporal sarcoma of the facial nerve. Arch. Otolaryng., 52:778 (November) 1950; e) Melkersson's syndrome - Report of five cases, with special reference to the pathologic observations. Arch. Utolaryng., 46:341-360 (September) 1947; $f$ ) Facial palsy of otitic origin. Arch. Otolaryng., 37:303-348, 1943; g) Prognosen for nervesutur og nervetransplantation ved perifer traumatisk facialisparese. Nord. Med., 43:1066, 1950; $h$ ) The prognosis of nerve grafting and nerve suture in peripheral facial palsies. Acta Otolaryng., suppl. 74, pg. 180, 1948. 23. Lathrop, F. D. - a) Facial nerve surgery in the European theater of operations. Laryngoscope, 56:665-676 (November) 1946: $b$ ) The practical anatomical and surgical considerations for exposure of the tacial nerve. Laryngoscope, 58:743-760 (August) 1948; c) Affections of the facial nerve. Bull. New York Acad. Med., 28:796-808, 1952; d) The facial nerve: technique of 
exposure and repair. S. Clin. North America, 33, no. 3 (June) 1953; e) Affections of the facial nerve. J.A.M.A., 152:19-25 (May 2) 1953. 24. Lewis, T.; Pickering, G. W.: Rotschild, P. - Centripetal paralysis arising out of arrested bloodflow to the limb, including notes on a form of tingling. Heart, 16:1, 1933. 25. Loomis, G. L. - Histamine treatment of Bell's palsy. Arch. Otolaryng., 52: 948, 1950. 26. Martin, R. C. - Prognosis in traumatic peripheral facial paralysis. Laryngoscope, 61:1004 (October) 1951; b) Bell's palsy. Arch. Otolaryng., 55, no. 4 (April) 1952. 27. Mayer, J. - Zur Genese und Prognose der otogenen Fazialisparesen. Wien. Med. Wchnschr., no. 16, pg. 302, 1952. 28. Melkersson, E. Hygiea, 90:737, 1928. 29. Minkowski - Zur pathologischen Anatomie der rheumatischen Facialislähmung. Arch. f. Psychiat., 23:586, 1891. 30. Mirallié, M. C. -Paralysie faciale périphérique; autopsie. Rev. Neurol., 14:702, 1906. 31. Morris, W. M. - a) Surgical treatment of Bell's palsy. Lancet, 1:429, 1938; b) Surgical treatment of facial paralysis. Lancet, $2: 558,1939 ; c)$ Surgical treatment of facial paralysis, Lancet, 2:1172, 1936. 32. Mygind, S. H.; Dederding, D. - Bidrag til de "rheumatiske" facialis paresers pathogenese og behandling. Dansk Otolaryng. Selsk. Fohandl., pg. 12, 1929. 33. Müller, R. - Facial paralysis; a follow-up study of 209 cases. Acta Med. Scandinav., 142:284, 1952. 34. Panneton, I'. 'lentative d'explication des paralysies faciales périphériques improprement appelées "a frigore". Zentralbl. f. Hals-, Nasen- u. Ohrenh., 29:639, 1938. 35. Parkc and Watkins - Cit. by Müller 33. 36. Philipp - Cit. by Winternitz 49. 37. Rasmussen, H. - Den otogene facialisparese med saerlight henblik pa behandìingen. Nord. med. (Hospitalstid.), 28:2214, 1945. 38. Rothendler, H. H. - Bell's palsy treated with cortisone. Am. J. M. Sc., 225:358 (April) 1953. 39. Skinnner, D. A. - a) 'l'he use of histamine in Bell's palsy. Ohio Stite M. J., 45:565-566, 1949; b) The treatment of Bell's palsy with histamine. Ann. Otol., Rhin. a. Laryng., 59:197 (March) 1950. 40. Skoog - Private communication to the author. 41. Sullivan, J. - a) Facial nerve-plasma glue. Private communication; b) Modern Practice in Diseases of the Ear, Nose and 'Throat. Vol. 2, Section 1: Ear. Chapter 8. Injuries to ear (middle and inner); $c$ ) Recent advances in the surgical treatment of facial paralysis and Bell's palsy. Laryngoscope, 62:449 (May) 1952. 42. Sullivan, J. A.; Sith, J. B. - The otological concept of Bell's palsy and its treatment. Ann. Otol. Rhin. a. Laryng., 59, no. 4 (December) 1950. 43. Thomsen, K. A. - Overliebeplastik og corticotropin ved Melkerssons syndrom. Nord. Med., 49:718, 1953.44. 'l'ickle, Th. G. - a) 'The surgical treatment of facial paralysis. Loose-leaf Surgery of the Ear. Chapt. 14, pg. 355-365, 1938; b) Surgery of the facial nerve in 300 operated cases. Laryngoscope, 55:191-195 (May) 1945; c) Surgery of the serenth nerve. J.A.M.A., 136:969-972, 1948. 45. Tschiassny, $K .-a)$ The site of the facial nerve lesion in cases of Ramsay Hunt's syndrome. Ann. Otol, Rhin. a. Laryng., 55:158 (March) 1946; b) Eight syndromes of facial paralysis and their significance in locating the lesion. Ann. Otol., Rhin. a. Laryng., 62:671 (September) 1953. 46. Violé, $P$. - Experiences in surgery of facial nerve. Laryngoscope, 54: 455,1944 . 47. Waterman $\rightarrow$ Cit. by Winternit $\%$ 49. 48. Weddell; Feinstein; I'attle - Cit. by Feinstein 12. 49. Winternitz, P. -- a) Gibt es eine rheumatische Facialislähmung? Schweiz. Med. Wchnschr., 77:291-292, 1947; b) Gibt es cine rheumatische Facialislähmung? Monatschr. f. Psychiat. u. Neurol., 113:17-39, 1947.

Postkonto 302r9 - Hillerod, Denmark. 